\title{
Voice, body and the transmission of the real in documentary theatre
}

Article

Accepted Version

Taylor, L. (2013) Voice, body and the transmission of the real in documentary theatre. Contemporary Theatre Review, 23 (3). pp. 368-379. ISSN 1477-2264 doi:

https://doi.org/10.1080/10486801.2013.806318 Available at https://centaur.reading.ac.uk/33712/

It is advisable to refer to the publisher's version if you intend to cite from the work. See Guidance on citing.

Published version at: http://dx.doi.org/10.1080/10486801.2013.806318

To link to this article DOI: http://dx.doi.org/10.1080/10486801.2013.806318

Publisher: Routledge

All outputs in CentAUR are protected by Intellectual Property Rights law, including copyright law. Copyright and IPR is retained by the creators or other copyright holders. Terms and conditions for use of this material are defined in the End User Agreement.

\section{www.reading.ac.uk/centaur}

\section{CentAUR}

Central Archive at the University of Reading

Reading's research outputs online 


\section{Lib Taylor}

\section{Film, Theatre \& Television \\ University of Reading}

\section{Voice, body and the transmission of the real in documentary theatre}

For the actor in the verbatim work of playwright Alecky Blythe, listening to recorded speech is the key means to shape performance, and on stage the performer's body as much as his or her voice makes public the aural material ingested through the ear. The creation and delivery of performance by means of listening, speaking and embodiment in Blythe's London Road, ${ }^{1}$ her recent musical play at London's National Theatre, modified theatre strategies used in her other plays, including Come Out Eli, ${ }^{2}$ Cruising, ${ }^{3}$ The Girlfriend Experience ${ }^{4}$ and Do We look Like Refugees. ${ }^{5}$ To examine affective listening in the development of Blythe's performances, I have interviewed two performers who were part of The Girlfriend Experience project, Beatie Edney ${ }^{6}$ and Esther Coles, ${ }^{7}$ and also interviewed Blythe ${ }^{8}$ herself. The ways that they discuss and reflect on listening,

\footnotetext{
${ }^{1}$ Alecky Blythe (Book and Lyrics) \& Adam Cork (Music and Lyrics), London Road (London: Nick Hern Books, 2011): first performed at th Cottesloe auditorium, the National Theatre, London, 14 April 2011, directed by Rufus Norris: transferred to the Olivier auditorium, National Theatre, 28 July 2012.

${ }^{2}$ Come Out Eli by Alecky Blythe: first performed at the Arcola Theatre, September 2003, directed by Sara Powell.

${ }^{3}$ Alecky Blythe, Cruising (London: Nick Hern Books, 2006): first performed at the Bush Theatre, London, 7 June 2006, directed by Matthew Dunster.

${ }^{4}$ Alecky Blythe, The Girlfriend Experience (London: Nick Hern Books, 2008): first performed at the Royal Court Jerwood Theatre Upstairs, London, 18 September 2008, directed by Joe Hill-Gibbins: transferred to the Young Vic Theatre, London, 29 July 2009.

${ }^{5}$ Alecky Blythe, Do We look Like Refugees, with the Rustaveli Theatre Company, Georgia, 2010: first performed in Georgia, 2010: transferred to Assembly Rooms, Edinburgh Festival, August 2010: British tour began at the University of Reading (in conjunction with South Hill Park Arts Centre, Bracknell), 16 May 2011. ${ }^{6}$ Interview with Beatie Edney, 12 August 2009. http://www.reading.ac.uk/web/FILES/ftt/Beatie Edney 12th August 2009.pdf ${ }^{7}$ Interview with Esther Coles, 12 August 2009. http://www.reading.ac.uk/web/FILES/ftt/Esther Coles 12th August 2009.pdf ${ }^{8}$ Interview with Alecky Blythe, 16 September 2011. http://www.reading.ac.uk/web/FILES/ftt/Alecky Blythe 16th September 2011 . $\mathrm{pdf}$
} 
performance, and ideas of authenticity are contextualised in this article by brief analyses of two other cases where voices are played into the ear as part of the performance process. One is Clio Barnard's film The Arbor, ${ }^{9}$ a 'quasidocumentary' on the playwright, Andrea Dunbar and the making of her 1980 play The Arbor, ${ }^{10}$ which makes use of an oral script to which the actors lip-sync. The other comparator is the Wooster Group's Poor Theater, which, amongst other things, attempts to recreate, in Polish, a section of Jerzy Grotowski's Akropolis (which in turn draws on Wyspiański's 1904 poetic drama, Acropolis) via a process of mimicry that includes vocal impersonation. ${ }^{11}$

Blythe sees authenticity as the foundation for her work. For her, authenticity derives from the exact reproduction of recorded sound (and not just language) that is channelled and embodied from documentary source material through the actors to the audience. The authenticity of the performance depends upon the act of listening to the primary material and its very precise imitation by actors in performance. It is fidelity to an original that legitimates and gives integrity to her performances, even if the audience are unaware of the process by which the performance is realised. For the Wooster Group imitation aims to engage with a set of contrasting critical ideas whereby the process of replication exposes performativity and the inauthentic in the act of performance. For them an original is always inaccessible, and authenticity lies in the integrity of a performance that reveals the artificiality of theatre. Barnard's film presents an aural source text replicated by performers but, undermined by deliberate disruption of correspondences with the original, the performance thereby raises questions around documentary authenticity. While for Blythe, matching an original produces a truth, for the Wooster Group, imitation can only ever be simulation and for Barnard, documentary realism is destabilised by performance. Blythe, Barnard and The Wooster Group all reproduce, in very precise ways, what might be called primary material as part of their creative process, but in the differing relationships of their source material to

\footnotetext{
${ }^{9}$ The Arbor (Director: Clio Barnard; Artangel Media, 2011).

10 Andrea Dunbar, The Arbor (London: Pluto Plays, 1980): first performed at the Royal Court Theatre, London, 1980, directed by Max Stafford-Clark.

11 The Wooster Group, Poor Theater: A Series of Simulacra: first performed at The Performance Garage, New York, 18 February 2004, directed by Liz LeCompte.
} 
performance they question authenticity, realism and the function of the text in a postdramatic context.

Carol Martin maintains that one of the functions of documentary theatre is '[t]o elaborate the oral culture of theatre and the theatricality of daily life in which gestures, mannerisms, and attitudes are passed and replicated via technology' (italics in original). She cites the work of Anna Deveare Smith who 'uses tape recordings of her interviewees to both become possessed by them and to allow a separation between the actor's self and the other.'12 In most of Blythe's work recorded voice, actor's body and prosthetic technology are fused into a symbiotic entity. The separation between actor and source text is apparent less in the acting style itself than in the form the script takes and the audio technology which prompts the actors' performances. I will argue that Blythe's work exhibits a tension between documentary theatre (fidelity to a real source) and embodied performance (no written play text, emphasis on the presence of the performer's body/voice). In the final section of the article, I argue that this is a response to divergent currents in contemporary theatre. By exploring Blythe's work in comparison to other uses of technologies of listening in performance, I analyse what is at stake in apparently similar relationships between voice, body and performance. To examine the critical potential and limitations of Blythe's performances I will focus on London Road, but refer extensively to The Girlfriend Experience and Do We Look Like Refugees.

London Road derives from verbatim material, collected by Blythe via interviews with Ipswich residents. The London Road project was initially developed in the National Theatre Studio's workshop programme as an experiment in partnering musical composers and writers. Fifteen months after its opening for a short run in the smallest of the National's auditoria, the Cottesloe, where it received very positive reviews, ${ }^{13}$ London Road transferred to the largest space at the National, The Olivier, in July 2012, where it played to

12 Carol Martin, Dramaturgy of the Real on the World Stage (Basingstoke: Palgrave, 2010), pp. 23-24.

13 The production received 5 star reviews from The Evening Standard, The Financial Times, The Independent, the Independent on Sunday, The Mail on Sunday, Metro, the Sunday Express, The Sunday Times and Time Out. 
almost maximum capacity. ${ }^{14}$ London Road is not the only documentary play to achieve popular appeal; the National Theatre has programmed documentary work, for example David Hare's Permanent Way ${ }^{15}$ and Stuff Happens, ${ }^{16}$ which used verbatim methodologies, and Black Watch ${ }^{17}$ and Enron ${ }^{18}$ were both acclaimed for their entertainment as well as political value. What London Road shares with these two plays is an important musical dimension, which may function to dislodge the popular perception of earnest sincerity in documentary theatre thereby making it more entertaining, or it may provide a dynamic strategy for the destablisation of the real to promote critical insight. ${ }^{19}$

London Road follows the lives of the inhabitants of London Road, Ipswich during the period in 2006/7 when five women who worked as prostitutes in the area were murdered by Steve Wright, who was briefly a resident of London Road. ${ }^{20}$ It is narrated jointly by the characters, who recount shared events from their recent past. Framed by reference to the London Road in Bloom competition, an event developed by the residents to help restore the reputation of the road following the murders, the residents jointly tell the story not of the murders but of their experience of living in London Road while the murders were happening, but more importantly when Wright was arrested and later tried for them. The story is told in the past tense using direct address, though specific

\footnotetext{
14 Personal communication from the National Theatre Archive, London.

15 David Hare, The Permanent Way (London: Faber, 2003): first performed at the Theatre Royal, York, 13 November 2003, co-production with Out of Joint and the National Theatre, London: transferred to the Cottesloe auditorium, the National Theatre, London, 6 January 2004, directed by Max Stafford-Clark.

16 David Hare, Stuff Happens (London: Faber, 2004): first performed at the Olivier auditorium, the National Theatre, London, 1 September, 2004, directed by Nicholas Hytner.

17 Gregory Burke, Black Watch (London: Faber, 2007): first performed at the University of Edinburgh Drill Hall, the Edinburgh Festival Fringe, 5 August 2006, directed by John Tiffany.

18 Lucy Prebble, Enron (London: Methuen, 2009): first performed at the Minerva Theatre, Chichester, 11 July 2009, directed by Rupert Goold, in a co-production by Headlong Theatre, Chichester Festival and the Royal Court Theatre: transferred to Royal Court Jerwood Theatre Downstairs, 17 September 2009: transferred to the Noel Coward Theatre, London, January.

19 Derek Paget and Jane Roscoe, 'Giving Voice: performance and authenticity in the documentary musical', Jump Cut: a Review of Contemporary Media 48, (2006), 20 Steve Wright, who was ultimately convicted of murdering all five women, was arrested for the Ipswich murders on 19 December 2006.
} 
events are acted out as if in the present time of their occurrence. The main focus of the play is not on the victims and their families, but on the exposure of a warm, but sometimes troubled and prejudiced, community to the press during this period. Blythe maintains that the play is about a community coming together to 'try to heal itself'. ${ }^{21}$

\section{Alecky Blythe's Verbatim Method}

No one of Blythe's plays offers a blueprint for her methodology. With her first play Come Out Eli, she tested a system of developing verbatim theatre that she learnt from Mark Wing-Davey, ${ }^{22}$ who in turn was strongly influenced by Anna Deveare Smith, whose work he had directed. ${ }^{23}$ Thereafter Blythe developed that approach to create The Girlfriend Experience, Do We Look Like Refugees and London Road, which each derive from oral material. Blythe's emphasis is on the voice and she records the stories, conversations, comments and opinions of the real people who comprise the subjects of her plays. This is not very different to the approach of many other documentary and verbatim practitioners but her work diverges from the documentary theatre tradition in the use to which she puts recorded material. ${ }^{24}$ For The Girlfriend Experience, Blythe spent over a year recording the conversations of a group of women prostitutes in a 'parlour' on the south coast of England. She edited an enormous amount of recorded material into a 'sound text', which provided the 'script' for the play, reshaped for theatrical and coherent narrative and developed characters. The audio recordings themselves were the primary material, rather than a resource for a

${ }^{21}$ Blythe and Cork, 'Introduction', London Road, p. vii.

22 Blythe participated in Mark Wing-Davey's workshop Drama Without Paper at the Actors' Centre in 2001, which focused on the impact of recorded material fed into the ear of the actor during theatre performance.

${ }^{23}$ Anna Deavere Smith pioneered the use of recorded interviews for developing performance. She listened to recordings of her real subjects through earphones during rehearsals but removed the earphones for the performance. In 1998, Mark Wing-Davey directed a four-week workshop on Deavere Smith's House Arrest at the Mark Taper Forum in Los Angeles.

${ }^{24}$ David Hare collected material in a similar way for The Permanent Way and The Power of Yes (London: Faber, 2009): first performed in the Lyttelton auditorium, The National Theatre, London, 29 September 2009, directed by Angus Jackson. Robin Soans interviewed subjects for his play Talking to Terrorists (London: Oberon Books, 2005): first performed in an Out of Joint production at the Theatre Royal, Bury St Edmunds, directed by Max Stafford-Clark. 
written or transcribed text (though a written version was subsequently produced for publication). The 'script' comprised, therefore, not only the spoken words but also the vocal utterances (stumbles, repetitions and hesitations), and the accents, emphasis, colour, pitch, pace, intonation and inflexions of the original speakers. Performers repeated the exact sounds of the real person they played, whose voice they listened to through headphones throughout rehearsal and performance, including the peripheral oral sounds such as breath, coughs, sighs, moans, sniffs and tuts. The actors never received a written script. Prior to auditions they were sent a CD of voices and in early 'read-throughs' or 'listenthroughs' the text was conveyed via headphones to each member of the production team and not via a communal loudspeaker system. ${ }^{25}$ The actors worked by listening to and precisely repeating the words and vocal expression of their 'real' counterparts to create the performance. As Esther Coles, who played Amber explains, they aimed never to speak with the characters, or 'on top of them' in rehearsal or performance, but rather one beat after they heard any utterance or vocal sound in the recording. ${ }^{26}$ At the same time, they were listening to the recorded sound of other characters through the earphones, as well as responding to the performance of the actors playing those characters.

The actors were connected somatically to the sound recording via the headphones they wore throughout; as Coles said, 'You're bound to the tape, you're bound to your voice and your character.'27 For the actors, listening was their primary function, signalled in Blythe's early work by the visible presence of the playback technology: 'we were all working with mini-disc players plugged in to one another, so it was kind of evident that we were being fed, almost speaking in tongues, channelling these voices.'28 The Girlfriend Experience used more sophisticated wi-fi technology, so the interconnection of actors and equipment was less tangible, although there was no attempt to hide the performers' largish headphones. The deliberate presence of the technology functioned indexically to give the process of listening a materiality fundamental to the creation of each performance, but with its aural complexity inaccessible to the audience. The

\footnotetext{
25 Interview with Edney, p. 2.

${ }^{26}$ Interview with Coles, p. 4.

27 Interview with Coles, p. 4.

28 Interview with Blythe, p. 8.
} 
process presumes that, by continual listening to the recorded voices, the actors will gain an insight which they can convey to the audience, another group of listeners, by accurately echoing the sound they hear. In The Girlfriend Experience the real women confess their most intimate personal details directly into the ears of the actors who then speak on their behalf, taking their place and passing on what they have said. As Edney said of her character, 'Basically, this might be Suzie but it's Suzie filtered through me ... you're sort of channelling the person.'29 Coles said they 'got inside by listening to the voice ... by osmosis you become the character' ${ }^{30}$ Faithfully matching what the women had said was experienced by the actors as a legitimation of the performance, and Blythe's devising process solicits an expectation of authenticity. In fact-based performance, the audience looks at and through the performer in order to see beyond him or her to the real person who preceded the representation. In Blythe's work, that sense of looking through becomes listening through, and thus draws attention to the materiality of voice and the sonic dimension of embodiment. In some documentary processes, for example Hare's Permanent Way, the actors themselves help to collect documentary material and meet the real people they later embody. In Blythe's method initially the actors are confronted only with their character's voice, and even though some do meet the people they are portraying at a later stage in the creative process, it is the voice that becomes the source of embodiment. Blythe prefers the actors to have the volume of the voices they are listening to turned up high, to engulf the performers emotionally and physically, and by a process of symbiosis actors feel possessed by the disembodied voice replayed in their heads, suggesting a psychic medium's relay of the voices of the dead. ${ }^{31}$

For Blythe, listening to the voice produces a match between the actor and the person portrayed, so that the material heard and transmitted authorises the performed embodiment. But resemblance between source and embodied character is not itself physical: both The Girlfriend Experience actors I interviewed had been told by audience members (who knew the people they portrayed) that they were like the real women even though the actors barely

\footnotetext{
${ }^{29}$ Interview with Edney, p. 8.

${ }^{30}$ Interview with Coles, p. 5

${ }^{31}$ Interview with Edney, p. 6.
} 
resembled their characters physically. Physical replication focused on what was referenced in the vocal text, for example changing the colour of Edney's hair. ${ }^{32}$ Coles never saw the woman she played yet a friend of her character said:

'You were so like Amber [...] but you know you don't look anything like her', because out of all of us I know I really don't look like my character but she said, 'you had something, you, that was sooo like her'. ${ }^{33}$ Edney, on the other hand, met her character, who had been instrumental in setting up the project with Blythe and who gave a lecture on aspects of her job, including statistical information on prostitution. But Edney did not feel this meeting was essential to her portrayal. She stated, 'I was getting a lot of physicality from the voice anyway ... I don't think it is necessary to meet the person to play them'. ${ }^{34}$ Rather Edney and Coles seem to 'take after' their source, 'reminding' friends of the people they know, partly through the tune of the voice, but also a tilt of the head, a movement of the chin, even a physical posture. Blythe notes:

Actors would have done training in voice work [...] they know about how to use their mouths to make sounds. [...] [A]s they copy the voice more precisely they have to put their faces into the shape that is actually how that person's face is, because in order to make that sound ... they become them physically by becoming them vocally. ${ }^{35}$

As Cicely Berry says in her training manual, 'vocal sound and speech is the result of physical action,' and just as adjusting bearing changes the voice, so shaping the voice forms demeanour. ${ }^{36}$

Speech, vocal sound and physical embodiment are experienced by Blythe's actors as a complex of characterisation in which voice takes the lead. The recorded text thus becomes a kind of score which determines not only how the characters speak and sound but how they move, stand or sit since, for example, the speed, energy and cadences of the dialogue and the hiatuses in the

\footnotetext{
32 Interview with Edney, p. 5

33 Interview with Coles, p. 15.

${ }^{34}$ Interview with Edney, p. 4.

35 Interview with Blythe, p. 10

${ }^{36}$ Cicely Berry, Your Voice and How to Use it Successfully (London: Harrap, 1975), p. 21.
} 
spoken text shape physical rhythms and patterns of movement. ${ }^{37}$ Blythe notes that Rufus Norris, in a bid to theatricalise performances in rehearsal, tried to direct the play in ways that conflicted with the rhythms dictated by the speech:

If you make the actor run around the stage and [be] more active then he would be out of breath, but when you hear it on the tape they're sitting down, they're relaxed. So Rufus was trying to give it a little bit more dynamism but sometimes it would ... they could just break the material, you know it doesn't work. 38

Bodily gesture, pose and spatial relationship are circumscribed by the constraints of the physicality required by the oral expression.

The notion of being 'in the moment' takes on a new and significant meaning for Blythe's actors, complicating its connection to naturalism and spontaneity. The actors emphasise that they aim to sound as if their performances are organic and spontaneous events; Edney insists, 'What you're trying to do if you're a good actor is be in the moment ... on the stage, always, and this technique absolutely forces you to be in the moment. And so you are very natural and ... as we are in life, as people are in life.'39 But each 'moment' is layered and intricate, as Cole explains, 'We're ... listening to the tape, then we're listening to the other actress say her bit, then we're listening to our reply, and then we're replying. You know, there's quite a few things going on.'40 The actors are listening to and imbued with the original moment when the sound text was produced, whilst simultaneously existing as constructed characters in the moment of the fictionalised narrative created by the edited recording, and in the moment of the performance. This apparently unmediated matching of actor to role is actually a complex relationship of different times, voices and presences, premised on perfect mirroring but actually haunted by unavoidable delays, gaps and relays. The performance collapses the temporal separation between the verbatim source material and its stage embodiment to a limit point. While verbatim theatre commonly uses spoken testimony as a source for performance, conventional rehearsal and performance practice necessitates a delay, a deferral

\footnotetext{
37 Interview with Coles, p. 11.

${ }^{38}$ Interview with Blythe, p. 25

${ }^{39}$ Interview with Edney, p. 2.

${ }^{40}$ Interview with Coles, p. 3.
} 
between the source material and its corporeal refiguration. Blythe's technique privileges the original spoken source, pressurising and condensing the deferring interval between source and embodiment. The physical imbrication of the audio technology in the body of the performer and its use to generate almost simultaneous performed speech, emphasise the minimisation of both temporal and physical distance. Quotidian performativity is played out theatrically in each performance in a self-conscious way, but its process is hidden from the audience. ${ }^{41}$ The methodology becomes a way of achieving realistic performance, not a way of critically exposing cultural and artistic performativity.

\section{Voice, sound and embodiment: London Road}

In The Girlfriend Experience, apart from the male actor who played the role of all the prostitutes' clients, each performer played a single role and thus embodied it illusionistically. In Blythe's previous plays actors had played a range of roles, making distinctions between them through their production of voice and their physical performance, but for Blythe illusionistic characterisation has greater 'authenticity' and 'seriousness' than more reflexive performances:

[For Come Out Eli] in the casting process [...] we cast against gender and age [...]. I think I kept doing that with shows up until The Girlfriend Experience and that changed things for me a bit because that was the first piece where the actors, apart from the male actor, the actresses were playing one part throughout. [...] It felt less Brechtian and more like they were being the character rather than putting on the character. [...] I fought for that quite strongly in the casting process. [...] The way I did Come Out Eli now feels a bit gimmicky to me. [...] I feel now if the story's strong enough the show's not about the technique, it's about the characters and getting that story out there. If the drama in the story's strong enough then I don't need a cool gimmick to fall back on. [...] It's become less about the technique now that I've got more used to it, and more about just trying to tell the stories truthfully. ${ }^{42}$

\footnotetext{
${ }^{41}$ See Judith Butler, Bodies That Matter: On The Discursive Limits Of Sex (London: Routledge, 1993).

42 Interview with Blythe, pp. 8.
} 
In London Road and Do We Look Like Refugees, however, there was a return to some multi-roling, and despite Blythe's view of her own more recent work, in both these performances (in the UK) the aural text was filtered through a secondary procedure that transformed the text and intervened in the notion of the actor as direct conduit between real person and the audience. London Road set parts of the verbatim text to music, and Do We Look Like Refugees presented verbatim material in Georgian via its actors while offering an English translation simultaneously as surtitles. In both cases, those transformations made the verbatim mode and the necessarily constructed nature of the text more available to the audience by a reprocessing of the aural material, drawing audience attention to the vocal dimension of the script and how the performativity of producing speech and non-verbal sounds might deconstruct authenticity. I return to the performance of Do We Look Like Refugees below.

In order to develop the script of London Road, Blythe used the same process of collecting material as she had in her earlier work, visiting Ipswich on several occasions and interviewing groups of people. As with much of her work, she collected the recorded material before she was sure how it would be used theatrically:

[M]y first lot of interviews [in December 2006], which show that everyone's very, very nervous, [were] from basically before [Steve Wright] was [...] arrested. With that lot of material which was maybe, I dunno ten hours or something like that, I collected it over a few days over that period just before Christmas 2006. That sat on my shelf for six months. [...] I thought I got down here too late. [...] [T] he trials played into my hands by being in Ipswich. So it was then six months later when I went back, after having used it as material to work with Adam [Cork], never thinking we'd make something out of it, and then finding the story of the residents. ${ }^{43}$

It was following her Spring 2007 visit that the National Theatre Studio gave Blythe the opportunity to participate in collaborative theatre workshops. Blythe was paired with a composer, Adam Cork. Following some early experimentation the recorded Ipswich material became the basis for the development of a musical

\footnotetext{
${ }^{43}$ Interview with Blythe, p. 4.
} 
drama and this took Blythe's work in a new direction; one which required her to adapt and rethink her process.

The London Road narrative is presented by a combination of spoken text and song, in which the actors function as a chorus, but take on one main role as well as several subsidiary ones. This approach is a mix of the previous forms adopted in Blythe's work, but for the first time she worked with song. The characteristic earpiece of Blythe's earlier work, always a visual signifier for the audience of the audio text, is lost ${ }^{44}$ and 'the original delivery as well as the words are learnt', ${ }^{45}$ returning recursively to Anna Deveare Smith's foundational influence on Blythe. The use of song becomes the mechanism for a reflexivity that Blythe had not envisaged. The musical score is not unlike some of the choral and operatic work of the American composer John Adams for example, with its relentless repetition of sound patterns and refrains, its use of everyday speech to create rhythm and tune, and the interweaving of melodic patterns that form the exchanges between characters. The characters slide almost imperceptibly from speech into song and back again, with almost no apparent hiatus between them. The lyrics of the songs come from the verbatim material and the melodies are constructed from the tune of the original voices. Cork comments:

Whenever I've set conventional texts to music, I've always spoken the words to myself, and transcribed the rhythms and the melodic rise and fall of my own voice, to try and arrive at the most truthful and direct expression of the text. And here was an opportunity to refine that to a much purer process, without any authorial poetic interpretation [...] polluting the connection between the actual subject and his or her representation in music. ${ }^{46}$

Cork attempted to produce a musical score that reflected Blythe's devising process, by retaining a connection to the rhythms, tone and musicality of the original speech, as well as remaining faithful to the actual words spoken, in order to maintain authenticity and honesty in its reflection of the people of London Road:

${ }^{44}$ Nicholas Hytner insisted the earphones were removed for performances (Blyth interview, p. 14).

45 Blythe \& Cork, 'Introduction', London Road, p. vi.

46 Ibid, p. viii. 
I wanted to find a way of singing with the quality of speech, which is altogether different from either an operatic or conventional musicaltheatre vocal style [...] representing the music of the speech rhythms with increasing forensic zeal [...]. The lack of rhyme or consistent meter or line length in spontaneous speech, even after we've structured the recordings into 'verses' and 'choruses', results in labyrinthine tunes which offer hardly any repetitive potential in themselves, as rhythmic or melodic material. So our instinct has been for the most part to contain these anarchic lines within fairly solid musical structures, and these containers are often built out of key elements of the transcribed voice, translated into harmonic progressions, or rhythms in the accompaniment. ${ }^{47}$

This process draws attention to the voice and deploys vocal authenticity differently from the forms adopted in Blythe's previous plays. The production of the voice in verbatim theatre is always problematic, because the aim to embody the real person can raise the spectre of mimicry akin to comic impersonators, and the actors in Blythe's work recognise this by sometimes using the term 'mimicry' to describe their work. ${ }^{48}$ But in London Road the sung dialogue becomes a means to foreground the artificiality of the apparent verisimilitude of the characters, so that the audience listens to the realism of the language in a new way:

Song - 'Everyone is Very Very Nervous' (continued)

RADIO DJ. Obviouslyyou gotta lotta people goin' outf' th' weekend th'gonna be a be worried So erm we're handing out personal alarms to erm a t' sort of ladies out shopping today So that, so that's why we're here.

ALL. Obviously you gotta lotta people goin' out f' th' weekend th'gonna be a be worried So erm we're handing out personal alarms to erm a t' sort of ladies out shopping today

\footnotetext{
47 Ibid, p. ix-x.

${ }^{48}$ Interview with Edney, pp. 3, 8; interview with Coles, p. 2.
} 
So that, so that's why we're here. ${ }^{49}$

The formalization of speech through the precise but musical reproduction and repetition of phrases disrupts the illusionism of the vocal text to make the audience aware both of the genuineness of the language, which gives the piece its legitimacy as verbatim theatre, but also of its constructedness as a piece of musical theatre.

Voice continues to take the lead in Blythe's quest for transmitted authenticity, but in London Road the music complicates this process more successfully than the ways that staging decisions disrupt the realism of The Girlfriend Experience. In The Girlfriend Experience, non-naturalistic elements such as the continual presence of the actors' earphones throughout the performance, the technician visibly controlling the audio text on stage, and the obvious theatricality of the stage set, did not vitiate the illusionistic representation of the characters. Direct address to the audience placed spectators within the parlour rather than functioning critically to distance them from the performance. But the systematic disruption of everyday language via song and musical accompaniment in London Road, by contrast, develops a critical approach in which the verbatim text is always evidently theatricalised and manipulated. While voice continues to 'channel' the voices of real people as a means to generate an impression of authenticity, music underscores how voice and embodiment on stage defer that matching of performance with its unseen source. The communality of the real London Road residents is both embodied but also replaced by the elaborate and spectacular communal performance of speech and song on the stage.

\section{Voice, body and role in The Arbor}

Clio Barnard's 2010 film The Arbor provides an interesting point of comparison to Blythe's work, in its use of recorded voice as a strategy of critical realism. The film centres on Andrea Dunbar, the young playwright who wrote the plays The Arbor and Rita, Sue and Bob Too, based on her experience of living on the

${ }^{49}$ Blythe and Cork, London Road, p. 13. 
Buttershaw Estate in Bradford. ${ }^{50}$ Dunbar died of a brain haemorrhage in 1990 at the age of 28, never having fully escaped the deprivation of her childhood and leaving behind three children from different men. The film interweaves several spatial locations and temporalities as well as different filmic and theatrical genres. These include archive footage of Dunbar and her family, from the late 1960s with their voices on the soundtrack; the stories her children told about their lives in interviews recorded with Barnard, embodied on screen in the film by actors; an account of the circumstances surrounding the development of her first play, The Arbor, with theatre director Max Stafford-Clark; and fragments from an open-air performance of the play, staged for Barnard's film in the centre of the Buttershaw Estate for an audience of local residents. ${ }^{51}$ Barnard uses recorded interviews with real people to create the script for the majority of the film, editing it to juxtapose fragments of narrative, strands of history and the scenes from the performance of The Arbor. Barnard uses recorded voice differently from Blythe, for although oral material is primary, instead of actors simulating the voice of the person they hear, in The Arbor the voices of the real people form the soundtrack of the film and the actors lip-sync with those voices. Although the distinction between actor and character is physicalised in the separation of voice and body, that dislocation is not apparent to the audience. Barnard and her actors work to match voice and lips exactly, like Blythe taking account of every hesitancy, cough and splutter, so there is no apparent disjunction to critically foreground the oral resources from which the film is constructed. The voice is the real, while the body (to differing degrees) is a performed and constructed assemblage. The Arbor draws attention to performed dislocations, if not in the vocal dimensions of the film, then in the critical displacement present in the bodily performance. The film represents its real people with differing levels of corporeal performativity and also through the different genres of documentary, reenactment and filmed theatrical performance, whereby slippages between character and actor can be clearly detected.

50 Andrea Dunbar, Rita, Sue And Bob Too (London: Methuen, 1988): first performed at The Royal Court Theatre, London, 14 October 1982. ${ }^{51}$ Archive footage of the Dunbar family was from Look North (BBC regional news) and Arena (BBC2, 1980). 
The figures represented on screen have differing levels of familiarity for the audience, though perhaps none is well-known to the general public. StaffordClark is probably the person with the strongest public persona, particularly for those familiar with Dunbar's story and/or the work of London's Royal Court Theatre. Dunbar herself would not be widely recognised, and her children not known beyond their circle of acquaintances. Though most members of the audience are unfamiliar with Dunbar's parents, they appear with the real Dunbar in the archive documentary sequences in The Arbor. This gives all three a doubled representation, since they also feature in the reenacted performance of Dunbar's play on the estate, a fictionalization of her own life, and this is one of the film's means of juxtaposing and problematising the real and the represented. This motif of doubling occurs across the entire film, so that the separation of real person, character and role makes apparent the artifice of both theatre performance and documentary performance of self. The representation of Stafford-Clark, the director of the original theatre staging of The Arbor play and ironically a figure central to the development of verbatim theatre, provides one of the most disconcerting performances. ${ }^{52}$ The actor Danny Webb impersonates Stafford-Clark and visually foregrounds artificiality by means of his wig, costume and demeanor. While there is an exact vocal matching of Stafford-Clark's recorded words with Webb's lip-sych, there is a disjuncture in the embodiment of the role. Webb also plays Dunbar's father, thus commenting critically on performativity. The performance looks sufficiently like Stafford-Clark for an informed audience to recognise him, but the physicality subtly but perceptibly mismatches the real person enough to reveal the masquerade. The audience cannot make the same judgment about Dunbar's children in the film. They are played by largely unknown performers and their performance style is hypernaturalistic, closing the critical gap between real person, character and actor, but the presence of the doubled characters and the evident impersonation in other roles works to undermine the realism and documentary authenticity of all the characters. Furthermore, the audience for the film's performance of the

52 Max Stafford-Clark developed a verbatim performance, 'A State Affair', Rita, Sue and Bob Too: and A State Affair (London: Methuen, 2000), based around the people living on the Buttershaw Estate, with Robin Soans in 2000. 
play The Arbor on the Buttershaw Estate are its real residents, while the people in the play are clearly actors playing roles, but playing the fictionalised members of the Dunbar family who were, in reality, their neighbours.

Blythe's London Road may not have the layers of Barnard's film, and the two works differ significantly in their representation of real people to dislodge authenticity and draw attention to their construction. But both Blythe and Barnard work to match voice with body whilst also disrupting complete correspondence. For Blythe the close imitation of the voice in order to capture character authorises her work, even in London Road, but its music intervenes in the matching of character and actor. For Barnard there is a separation of real person, character and actor in some of the film's embodiment but the lip synching of the body 'on top of the voice' sutures the elements together. Both works introduce deferrals of the realist matching of voice to real person, and offer the audience a layered experience in which authenticity is refracted. Music is the primary mechanism for this in London Road, while The Arbor uses a complex interweaving of casting decisions, performance style, mixed filmic genres and theatrical re-presentations.

\section{Translation, writing and voice: Do We Look Like Refugees and The Wooster}

\section{Group's Grotwoski Project}

Do We Look Like Refugees, devised with Rustaveli Theatre, was performed in Georgian, with actors speaking the lines as they heard them through their earpieces in performance, but in the UK, the translated written text was projected as surtitles on the wall above the heads of the actors. Originally conceived as a workshop production at The National Theatre's Studio, and supported by the British Council, Do We Look Like Refugees was a verbatim performance developed in Georgia by Blythe, who spent a week in refugee settlements at Gori and Tserovani. It focused on the lives of displaced Georgian people, housed in a refugee settlement near Tbilisi, who lost their homes after the 2008 Georgian-Russian war. Though Blythe spoke no Georgian, working with translators she developed the script by editing interviews with people in the refugee camp. The performance was presented in Georgia by the Rustaveli Theatre Company, before going to the Edinburgh Festival in 2010. Up to this 
point, the play could be seen as functioning in a similar way to The Girlfriend Experience or, since each actor played several roles, to Come Out Eli. The actors listened to the speech of the characters they were playing, replicating the aural material in minute detail. For a British tour a means of translation of the verbal material was required, one that allowed the audience access to meaning while also enabling them to experience the authenticity of verbatim dialogue and thereby, as Blythe sees it, access the integrity of the characters. Surtitles are not unusual in international theatre (while dubbing, so common in film, is rare) but their deployment in Do We Look Like Refugees was not only a pragmatic means of translation but also a critical device, not unlike the music in London Road:

We grappled over the how much detail should go into the surtitles because there were no 'ums' and 'ahs' in those surtitles. [...] I did condense a lot and just hope that you could hear the 'ummmerr' in the delivery of the speeches. ${ }^{53}$

The sonic source material, intended to give access to the real through its origination from the initial interviews, existed simultaneously in three material forms in the performance itself, even if all of them were available to very few people in the theatre. The edited recordings played through the earphones of the actors were accessed only by the actors and the technician who operated the playback equipment, the verbal text spoken by the actors was listened to by everyone in the theatre but was understood only by Georgian speakers (mostly the theatre company), and the written transcript in English, projected onto the wall, was understood only by those who spoke English (mostly the audience). The written transcript could not be seen by the actors, which meant that in all likelihood the only person to have access to all versions of the play in performance was a technician operating the surtitles.

Voice was processed not only like other Blythe scripts, as a sound text, but also during the performance itself until it became something unrecognizable to the original interviewees and some of the actors. Furthermore, Blythe was dependent on an interpreter during the editing process, so that, although she could hear the tune of the voices, she did understand the detail of what was said. During performances, she and the English-speaking audience listened to voice as

53 Interview with Blythe, p. 21. 
sound patterns, not unlike the tunes for London Road. Yet the play claims an authenticity and a connection to the real commensurate with The Girlfriend Experience or Come Out Eli. Most of the audience was piecing together vocal sound dissociated from, but connected with, their reading of the translated recordings, on surtitles which were largely devoid of the repetitions, hesitations, interruptions and ellipses characteristic of the recordings and the performed utterances of the actors. The spoken Georgian included all the extra-linguistic information of coughs and splutters, and through the timbre and quality of each voice, seemed to offer insight into character and access to the real person portrayed on stage. This was never a naturalistic performance, and indeed most of the actors played more than one role and the minimal stage setting was close to a Brechtian model. But the material presence of a written text meant that the transcription and editing process of the play's creation became more available to the English-speaking audience during the performance, and the artifice of representing voice and language to create character and narrative became more apparent. Blythe's characteristic practice of basing the performance on voice as a means of access to an essence of character and story was put into question.

The Wooster Group, on the other hand, use voices played to the actors via headphones in performance in a very distinct way, quite different to Blythe's. The headset including earbuds and microphone worn on the head of performers is a very familiar prop in many Wooster Group performances, including recent examples To You the Birdie, ${ }^{54}$ Vieux Carré 55 and Troilus and Cressida, 56 but the voices the performers listen to do not necessarily comprise the text they are speaking. The voices offer a text against which the performance is constructed: the soundtrack of a film, comments fed in by the director, Liz LeCompte, which may or may not inflect the current performance, or a text related tangentially to the topic or performance to refocus or deepen the actors' engagement. Even where the oral text does provide at least part of the script spoken by the actors,

${ }^{54}$ To You The Birdie, The Wooster Group, directed by Elizabeth LeCompte: first performed at The Festival D'Automne, Centre Pompidou, Paris, France, 2001. 55 Vieux Carré, The Wooster Group, directed by Elizabeth LeCompte: first performed at Festival Premieres at Théâtre National, Strasbourg, France, 2011. 56 Troilus and Cressida, The Wooster Group (with the Royal Shakespeare Company), directed by Elizabeth LeCompte (with Mark Ravenhill): first performed at The Swan Theatre, Stratford on Avon, 3 August 2012. 
the deliberate disjunction of aural and spoken script functions reflexively to foreground performance and artificiality. In their recent version of Hamlet, based around the Richard Burton Broadway version of the play, directed by John Gielgud in 1964, the company attempts to reconstruct the theatre performance visually and orally from the fragmentary evidence of an edited film version of the production. They state, 'We channel the ghost of the legendary 1964 performance, descending into a kind of madness, intentionally replacing our own spirit with the spirit of another.'57 The voices played in the ear are the unsettling, ghostly presence of an absent and inaccessible original, while for Blythe's actors the voices in the head are the lingering spirit that authorises their work.

For the Wooster Group, the aural material is intended to destabilise the performance rather than provide access to the real, and thus it is a means for dispelling the illusory and exposing the artificiality of theatre. The Wooster Group's re-enactment of the last twenty minutes of Grotowski's Akropolis as Part 1 of their performance Poor Theater, however, offers significant points of comparison as well as contrast with Blythe's verbatim theatre forms. In their version of Akropolis the company aim to present a reconstruction of the iconic 1965 Grotowski performance based on Stanislaw Wyspiański's 1904 play. The company works through a process of self-conscious imitation, not only of the physical performance - the version of the play filmed in London in 1968 is played to them on screens around the stage - but also of the text relayed to them via headphones. The text is in Polish, a language few members of the Wooster Group speak with assurance, and consequently the text is reproduced by copying the sound of the speech without access to the meaning of the words. Rebecca Schneider comments:

The fervor of exactitude in their reenactment (that is, they don't attempt to reinterpret as much as to precisely repeat) seems like an attempt to clone the forebears, as precisely as possible: the tiniest or most specific of Growtowksi's Lab actors' details are attended to - tilt of head, toss of hair, stamp of foot, furrow of brow, pitch of voice, direction of gaze, intake of

${ }^{57}$ http://thewoostergroup.org/twg/twg.php?hamlet (accessed 17 November 2012). 
breath. Exact particulars of affective, gestural, and aural bits (without, interestingly, attention to replica costume or make-up or other conventions of historical reconstruction) are attempted in replay across the bodies of the Wooster actors who play their efforts at exactness on a stage rendered as a "footprint" of the Wrocłersaw stage. 58

The printed script is only of value to those who understand the visual signs of the written words, just as a musical score is only of value to those that read music. The aural source text is a soundtrack of a recorded version of an earlier performance, which the actors listen to and replicate as if, as in music, playing or speaking - 'by ear', and similarly the actors in London Road not only replicate recorded voice 'by ear' (though without earphones), but also use similar techniques to animate the musical dimension of the play. ${ }^{59}$

Like Blythe's performers, the Wooster Group actors replicate all the details of this vocal score including the tune of the voice, the pauses, emphases and hiatuses, and like Blythe's performers they require a moment's delay to ingest the sounds before regurgitating them. Unlike Blythe's performers, they do not comprehend the detail of what they are saying nor how pauses and emphases, tonal shifts and inflections, and modulation and phraseology relate to the nuances of meaning. For the Wooster Group the important relationship of voice and bodily performance (also a facsimile of the Grotowski performance) to the Polish original, is not one of matching and stability but one that exposes the disjuncture of body and voice as sign systems and reveals the artificiality of performance 'languages'. At the other end of the spectrum, Blythe's performances use the soundtrack of voices to give credence to the performance, to defer its relationship to fiction and emphasise its significance as authentic documentary.

\section{Engaging the real}

58 Rebecca Schneider, Performing Remains: Art and War in Times of Theatrical Reenactment (London: Routledge, 2011).

${ }^{59}$ Blythe explains that she went through the oral text with the actors in London Road repeatedly, to capture the detail of the original interviews, even though they did not wear headphones to listen to their sources (Blyth interview, p. 13). 
Major questions have arisen around the function of text in theatre of the late twentieth and early twenty-first centuries. Theatre in this recent period no longer sees the writer as pre-eminent nor the text as sacrosanct, and instead, the supposedly more vital performative theatre of experimentation and personal experience has been acclaimed. In Postdramatic Theatre (1999/2006), Hans Thiers Lehmann describes a tendency in contemporary theatre to resist textual control, in favour of a live performance not dependent on textual prescription. ${ }^{60}$ Postdramatic theatre proclaims text as artificial and character and narrative as manufactured. The work on which Lehmann focuses deploys text as evocative, poetic, deliberately fragmented and non-linear, and not as the organising principle behind the theatrical event. At the same time, the mid-1990s saw a reemergence of strong new writing, mostly present in Britain in the explosion of work which spearheaded a profusion of new texts and a rekindling of interest in new writing by playwrights such as Sarah Kane and Mark Ravenhill. It marked a return to the robust, poetic, muscular text, almost Shakespearian in its ambition. Thus the play text might be seen as something that has been both repudiated and recast in new ways in the last fifteen years. Peter Boenisch defines an unhelpful opposition in theatre in the UK between 'supposedly innovative experiments with bodies and images on the one hand, and text-based theatre on the other,' and he identifies this 'friction' as 'a direct result of the dominant British theatre tradition which has, since the 1830s, established the authority of the playwright and the written word firmly at its centre.'61 Thus he sees contemporary UK theatre as caught between two connected but contrasting trends which might be characterised as physical theatre which de-emphasises text in favour of bodily performance and phenomenological experience, and contemporary forms of playwriting which place themselves in opposition to the literary codes of decorum and the formal refinement that the textual tradition is seen to represent.

This leaves a question as to where documentary theatre fits into this

\footnotetext{
${ }^{60}$ Hans-Thies Lehmann, Postdramatic Theatre, trans. by Karen Jürs-Munby (London: Routledge, 2006).

${ }^{61}$ Peter Boenisch, 'Towards a Theatre of Encounter and Experience: Reflexive Dramaturgies and Classic Texts', Contemporary Theatre Review, 20:2, (2010), 162-72 (p. 162).
} 
binary, since undoubtedly it has been a popular form in recent years. Its designations 'verbatim' and 'documentary' connect it to text-led theatre since it is based on recorded words and written documents but, in its aim to capture the experience, feelings and encounters of real people, it reflects a phenomenological focus on immediacy and liveness, which echoes Lehmann's notion of the postdramatic. ${ }^{62}$ The revival in documentary theatre in the late twentieth and early twenty-first centuries can be attributed to a conjunction of several factors. ${ }^{63}$ But that revival seems to support Martin's assertion:

More recently dramaturgical innovations in the ways texts are created and productions are staged shed light on the ways theatre can form and be formed by contemporary cultural discourses about the real both on stage and off. 64

New forms of theatre aim to elucidate discourses of the real, and at the same time, these connect with the postdramatic and new forms of theatre writing. Blythe's verbatim work re-presents oral interviews, thereby seemingly displacing the authority of the literary writer and aspiring to embody the performativity, aliveness and spontaneity of the act of speaking. Her verbatim theatre aims to offer immediacy and a direct communication with real people via a radical approach to the development of theatre projects even if the oral 'liveness' of the source text, which exists in a continual present for the actors, is lost to the audience. At the same time, the recorded vocal material in Blythe's work is a kind of 'writing' inasmuch as it is stored, edited and is published as a record to be revisited. Her plays may not be brutally shocking like the written texts of the in-yer-face canon (even though London Road is set amid violent real

62 See Janelle Reinelt, 'The Promise of Documentary', in Get Real: Documentary Theatre Past and Present, ed. by Alison Forsyth and Chris Megson (Basingstoke: Palgrave Macmillan, 2009), pp. 6-23.

63 See Forsyth and Megson, Get Real: Documentary Theatre Past and Present; Playing for Real: Actors on Playing Real People, ed. by Tom Cantrell and Mary Luckhurst (Basingstoke: Palgrave Macmillan, 2010); Derek Paget, 'Acting with Facts: Actors Performing the Real in British Theatre and Television since 1990 a preliminary report', Studies in Documentary Film, 1:2 (2007), 165-76; Lib Taylor, 'The Experience of Immediacy: Emotion and Enlistment in Fact-based Theatre', Studies in Theatre \& Performance, 31:1 (2011), 223-37. ${ }^{64}$ Carol Martin, Dramaturgy of the Real on the World Stage (Basingstoke: Palgrave Macmillan, 2010), p. 1. 
events) but she aims for an experience of vitality and engagement via a realism of speech asserted through her methodology as much as in the performances themselves. Furthermore, in Blythe's theatre, aurality as a strategy of authenticity based on the voice impacts upon a corporeal performance process.

In verbatim theatre the actor remains the visible and aural sign of documentary drama's inauthenticity as documentary while, at the same time, he or she is the equally visible and aural sign of dramatic performance (because of the absence of the real person being represented). London Road documents the reaction to the murders by the inhabitants of the street, embodying the authenticity of their voices through performance. As music theatre, London Road represents a shift in position for Blythe, since she moves towards embracing critically the reflexive mode of performance she characterises as 'gimmicky' in Come Out Eli and consciously resists in The Girlfriend Experience. ${ }^{65}$ The inclusion of the songs in London Road critically underscores the nature of the performance as simultaneously authentic and simulated, revealing the performativity of both the characters and the real people they represent. Voice in London Road both claims and defers authenticity and authority, inasmuch as the voice signifies presence and the embodiment of identity but the reworking of speech into sung tunes signals the absence of the real. The translation processes and refraction of voice into written surtitles has a similar effect in Do We Look Like Refugees. The category of 'documentary theatre' rather unhelpfully groups dissimilar devising processes and performance modes together. The work that it denotes includes forms of theatre that have other, overlapping categorizations and it draws attention to the tensions analysed in this article, where for example an examination of The Wooster Group's performances can become a productive critical comparator for assessing the work of a very different playwright such as Alecky Blythe. Blythe's work, Barnard's film and The Wooster Group's performances are a useful framework for addressing questions of presence and absence, voice and identity, authenticity and replication. While presence and subjectivity might reside in the voice, such innovative ways of working on enunciation with bodies in performance simultaneously construct rather than express the anterior identity that voice appears to body forth.

\footnotetext{
65 Interview with Blythe, p. 8.
} 